\title{
An Assessment of the Role of Art as a Resource for Learning and Development of the Child With Computer Applications*
}

\author{
Francis Okechukwu Amadi, Priscilla Ifeoma Okechukwu \\ Federal Polytechnic, Nasarawa, Nigeria
}

\begin{abstract}
An assessment of the role of Art as a resource for learning and development of the child has become necessary now that education appears to be the yearning of all especially in the developing countries. This paper seeks to assess the role of Art in learning and development of a child. The paper stresses that the child needs Art to learn because children's attention is drawn first by pictures (Art works) before letters of Alphabet. According to the paper, children become more knowledgeable and creative as they participate in Art classes where they are given opportunities to express themselves while engaging in drawing and painting exercises. This leads to self-discovery and development in children. By this, entrepreneurial spirit is also imbibed. The paper also notes that children who would not ordinarily want to learn have found pleasure in learning with Art and computer. Here the use of cartoons and animations become appropriate in teaching the child. Children also become more adventurous and creative as they find pleasure in drawing with application software like Corel Draw, Microsoft Paint, and so on. Finally, the paper emphasizes the need for Art to be wholly infused in the curricular of schools especially the primaries. This will be a strong factor or agent of development in children. Here the creative and inventive spirit so developed and imbibed will lead to discoveries of future entrepreneurs, industrialists and technologists for national developments.
\end{abstract}

Keywords: Art, child, development, creativity, learning, education, resource, computer

\section{Introduction}

Before now Art was not given a rousing welcome in Nigerian schools because other schools' subjects like English, Mathematics, Social Studies, Civics, etc. were holding sway against Art. In this regard, stakeholders of education in the ministry, headmasters and schools masters had erroneous impression about Art. There was the feeling that Art was more or less craft. People would feel very comfortable and good when their wards go to higher institutions to study Engineering, Pharmacy, Law, etc. and not Art.

Sad to say that people never recognized Art because they did not know what Art entails. Not knowing what Art entailed resulted in some derogatory statements made about the subject. They never knew that the study of other schools' subjects could not be possible without Art. Art is a foundational subject which every child requires

\footnotetext{
* Acknowledgements: The paper was presented at the International Conference on Arts and Humanities Holding in Colombo, Sri-Lanka, 2nd to 3rd April, 2014.

Francis Okechukwu Amadi, B.A. (Graphics), M.A. (Art Ed.), Department of Art and Industrial Design, School of Environmental Studies, Federal Polytechnic.

Priscilla Ifeoma Okechukwu, B.Sc. \& M.Sc. (Computer Science), Department of Computer Science, School of Applied Sciences, Federal Polytechnic.
} 
to learn and develop.

Today, people are becoming aware of the importance of Art in teaching and learning. This could be as a result of over the years' campaigns and teachings about the importance of Art in development. It is also not unlikely they have observed that the impartation of knowledge becomes more feasible with pictures and drawings. More so, the present computer age which has made drawing a part and parcel of learning, is making many people develop interest in Art. Basically Computer Studies to a large extent is emphasizing Art. The mouse that is attached to the computer is no doubt a drawing facility. In this regard, Art is being popularized and gradually becoming welcome in schools.

This all important subject should be made compulsory in both primary and secondary levels of education because, it will make teaching and learning easier and faster in our schools. At the tertiary levels of education, teaching and learning of courses like architecture becomes feasible and realistic because the skill that is needed in architecture is all embedded in the Arts. Mathematics largely depends on signs and symbols which are rooted in Arts. Literary subjects like English Language, English Literature require imagery, creativity and conceptions which are Art attributes.

More so, the study of Engineering becomes more feasible because artistic skills are applied in machine designs and product developments. Drawing in the first instance is the basis of all. This is the more reason why a child's learning could hardly be achieved without the involvement of Art. A child requires to see the picture or drawing of a ball to really know what it is. This will now be followed by learning the letters that form the word "ball”. In this regard, one can appreciate the level of the importance of Art in all ramifications of education.

Amadi (2011) emphasized that most technologically developed countries realized right from the outsets that the conditions most favourable to invention is to accumulate knowledge and experiences in Art and creativity. The importance of Art Education to the realization of physical growth and development of scientific and technological knowledge was fully recognized by the western world which had to make Art the basis of its learning. This is reflected in their efforts to ensure the development of the stages of the Artistic development in a child.

\section{Definition of Terms}

Assessment of the Role of Art as a Resource for Learning and Development of the Child.

Assessment: Hornby (2010) defined Assessment as an opinion or a judgement about somebody or something that has been thought about very carefully.

Role: The function or position that somebody has or is expected to have in an organization, in society or in a relationship (Hornby, 2010).

Art: Art is the deliberate or conscious employment of skill and "creativity" to produce visually aesthetic and other functional Art images. The word "creativity" is very sensitive here because it is what has made Art an uncommon professional phenomenon; that is, the ability to bring into physical reality what has not been. It is what has made it divine. This had also made God, the Creator, The First and Greatest Artist. This was probably what was in the mind of Sir Thomas Browne, the 17th Century physician, when he said, "Nature is the Art of God” (Oloidi, 2011).

Resource: (a) Somebody or something that is a source to help or information. 
(b) Adeptness at finding solutions to problems (Microsoft ${ }^{\circledR}$ Encarta ${ }^{\circledR} 2009$ (DVD) Redmond, 2008).

Learning: Acquiring of knowledge: the acquisition of knowledge or skill (Microsoft ${ }^{\circledR}$ Encarta ${ }^{\circledR} 2009$ (DVD) Redmond, 2008).

Development: The gradual growth of something so that it becomes more advanced, stronger, etc. (Hornby, 2010).

Child: Oloidi (2013) defined child as who can be a boy or a girl, son or daughter, usually between birth and teens.

Hornby (2010) defined child as a young human who is not yet an adult.

\section{The Importance of Art in Child Learning (Education)}

In the first place, Art is a great attraction to children. This is the more reason why children are somewhat addicted to pictures, beautiful buildings, and Art works of different kinds. In most cases children would like to visit museums, Art carnivals, and galleries, etc. After the visit they come back home and tell the stories for a very long time. They also feel good to tell the stories to their friends who have never been to such places.

A child of about $2 \frac{1}{2}$ (two and a half) years old walked into the office of the Director of the Federal Polytechnic, Nasarawa Consult with her mother and immediately pointed at a montage that hung on the wall and said, "Mummy see!”. The interesting thing about the situation is that there were calendars and other pictures on the wall within the office, but the child was only attracted to that piece of Art work. Another child, on the 26th of December, 2013 kept on flipping through an Art book over and over again, and when asked why she got interested in the book, she turned to the cover of the book and pointed at it. On the cover page were the designs of the collection of children's paintings. If children's attention would always be drawn by Art works, it becomes pertinent therefore that Art becomes the right medium with which to pass knowledge on to the children.

Amadi (2013) posited that drawings and illustrations have become very needful in the kindergarten and primary levels of education. The letters of alphabets as drawings have become very important factors in enabling the pupils know more about the letters as well as those objects like ball, cup, and chair, and so on they see everyday. In this regard, they are taught how to use the letters to express the objects. For example, "Letter B is for Ball" and "Letter C is for Cup".

As the pupils are taught how to use letters to represent objects, they are also taught how to draw these objects. By drawing the objects, their knowledge of both the objects and the alphabets become stronger because they look at the objects as drawn while pronouncing them. At this point, Art becomes the subject by which pupils can learn about their environment as well as the compositions of the environment. As the pupils learn, the drawings of the objects form in their subconscious with the letters of the alphabets that begin them.

Hurwitz and Day (2007) in Amadi (2013) emphasized that children produce drawings and paintings that say something about their reactions to experience and heighten their abilities to observe. Drawing activity is also a precursor to the development of writing skills. The correlation between drawing and lettering is particularly effective in Asian countries like Japan and China, where practice in calligraphy enlivens the quality of line.

In this regard, lettering which is also part of the Artists' invention, when combined with drawing (Art) in learning gives pupils or children the basis for learning all the schools' subjects; then understanding of the subjects becomes easier. Arithmetic requires the drawing of the geometric objects to know what a circle, triangle, square, 
etc. look like. More so, a literary subject like English would require drawings (illustrations) to express moods and sceneries which would last long in pupils' memories.

According to Emeriewen (2009), “Art is not just nice, it is necessary”. In this explanation, if Art is only something "nice" for children to have, after serious school work, then it has no place in the curriculum. After all, there are other numerous nice experiences for children to have, and anyone of them will do. But more importantly, a balanced education is that which includes the aesthetic domain of human experience that is found in a basic subject like Art. This posture has also increased that rational for integrating Art in the teaching of other elementary school subjects. Art provides a fundamental lens of understanding through which man views and interprets better his world.

Early exposure to Art helps the child to acquire skill and language to communicate non-verbally. By this a child learns to communicate with pencil on paper as well as with colours on paper. This helps the child to be imaginative as well as develop the innate ability to put his/her ideas, thoughts and feelings on paper. By this, great poets, painters, and writers have been made. This becomes possible because a child in most cases is given free hand to use the Art materials (paint, brush, and pencil) to work without interruption by the teacher who only acts as a guide. Adetoro (2013) posited that Art gives the children the ability to express their thoughts and emotional love before they can fully express themselves with words. This is universally agreed upon by scholars.

Lowenfeld and Brittain (1975) asserted that Art is a dynamic and unifying activity, with a potentially vital role in the education of our children. The process of drawing, painting, or constructing is a complex one in which the child brings together diverse elements of his/her experience to make a new and meaningful whole. In the process of selecting, interpreting, and reforming these elements, he/she has given us more than a picture or a sculpture; he/she has given us a part of himself/herself; how he/she thinks, how he/she feels, and how he/she sees.

When early education is started with Art for a child, the child or the children are bound to be aesthetic conscious. This means that through constant Art lessons, practices and classroom activities, a child would always aim at producing the best or the most beautiful works as compared with others. By this, a child becomes beauty or aesthetic conscious and would always ensure that whatever he/she does is beautiful.

Hornby (2010) in Amadi (2012) explained that aesthetics is concerned with beauty and Art, and the understanding of beautiful things. In this regard, it implies that Art is a vehicle and a conveyor of aesthetics. Through Art therefore, the sense of beauty or aesthetics could be developed. This is achievable through studies. Uzoagba (2000) also in Amadi (2012) confirmed that through Art education we acquire the faculty of aesthetics appreciation. He said further that aesthetics values infact permeate all the social and practical aspects of life. When children grow with this great Art resource their choice life will not only be affected but also their output in the Arts or any other career they might choose. For instance, it has been observed here in the polytechnic, that the best graduate over the years in architecture were those who are Art inclined. In the same vein, Oloidi (2013) asserted that Art makes the child have a sense of commitment and aesthetic judgment and induces in him/her a sense of value and occupational seriousness. In addition, it brings him/her environmental awareness and makes him/her see Art, as a practical act, as a delightful preoccupation that is also the beginning of having respect, rather than disdain for Art. Oloidi (2013) sited Albert Einstein and Winston Churchill as great men who had childhood experiences and studies of Art. Only few people know that Churchill, apart from being the Prime Minister of England, soldier and war commander who helped bring the 2nd World War to an end, was also a painter or a 
landscape painter, who did not forget his painting even at the peak of the war. Churchill's artistic instincts dated to his childhood Art interests. Seeing the importance of Art in child education it becomes pertinent that Art is made part of the curriculum of kindergarten, primary, and secondary schools education.

\section{Creativity Through Art Learning}

The word "Creativity" is very sensitive because it is what has made Art uncommon professional phenomenon, that is, the ability to bring into physical reality what has not been (Oloidi, 2011, as cited in Amadi, 2012). Oxford English Dictionary (1989) in Amadi (2012) defined creativity as creative power or faculty, ability to create.

\section{Attributes of Art in Other Professions}

A critical look at these definitions, one would realize that Art is wholly associated with creativity. Other resources or attributes of Art like conception, imagination (imagery), aesthetics and skill make Art the only discipline that can evoke creativity. In this regard early Art education of the child is no doubt the beginning of a creative walk of the child into adulthood (See Appendix A). In adulthood the creativity would no doubt bring about inventions. The developed countries would have realized this truth and have not failed to make Art the basis of their education. At the kindergarten, primary and secondary levels, Art is made to take a driving seat because it is known that all subjects hinge on Art, and that the future medical doctors, engineers, architects, inventors, etc. will be propelled by their studies and experiences of Art at those levels of education. Mbahi (1997) sited that the "civilized" countries of the western world have attained nearly the maximum height in the physical sciences in this era, they are still giving all facilities to encourage the Arts. Taking U.S.A. for example, Art is taught in all schools from the secondary school level down to kindergarten. They realize that Art is the basis of all disciplines and the foundation of discovery.

\section{At Birth, Art and Creativity}

As soon as a child is born, that creative instinct that the Creator (God) implanted in every man begins to manifest. Even though the child is yet to walk, he/she begins to make scribbles even without knowing it. The child could make fountains with a plate filled with water beside him or her by unconsciously using his/her hands to vigorously splash the water to form fountains. Sometimes when a plate of food is kept beside a child, he/she unconsciously draws what might look like a map on the food.

Lowenfeld and Brittain (1995) expressed the fact that creative growth starts as soon as the child begins to make marks. He or she does this by inventing his/her own forms and putting something of himself/herself in a way that is uniquely his or hers. From this simple documentation of oneself to the most complex form of creative production, there are many intermediary steps. Within the drawings and paintings of children creative growth can readily be seen in an independent and imaginative approach to the work of Art.

Oloidi (2013) added that we teach Art so that the creative urge in our children can be nurtured in such a way as to develop their innate qualities. Nigeria needs creative thinkers to try out new ways of doing things or make discoveries which may make life better. In the properly balanced education in other civilized (technologically developed) countries of the world, the importance of Art is emphasized from the very early days in the elementary school up to the secondary school. Categorically, we can assert that there is not a subject in any 
educational programme which will not profit immensely from an Art background and if you can think of any subject that would not gain tremendously from Art, please let us know. Akpaide (2006) stated that there is Art in everything man does. For example, from the Art of painting to literary Art; from the Art of organizing a home to the Art of governance; from the Art of fantasy of hut building to the Art of Architecture; from the Art of drawing to the Art of painting, photography and cinematography and so on and so forth, Art is involved.

The above statement by Akpaide may be making reference to aesthetics, but the facts remain that aesthetics is one of the resources or attributes of Visual Art and so Visual Art dominates all the fabrics of the mentioned professions. For instance, while thinking about the function of the products the manufacturer also have to think about the beauty (Art) which will make the product be acceptable to the buyers. In this regard Art becomes the foundational subject which a child should in the first place or instance be exposed to as this is the only thing that appeals to a child. The picture or drawing and the environment are all wonders to a growing child.

They appeal to the senses of a growing child and by these his or her imaginations are captured; and as the child grows he or she would like to create similar pictures, make toys, build houses with sand, etc. Emeriewen (2009) asserted that a picture, commonly said, is worth a thousand words. Art gives the young learner ample time and freedom to express himself/herself creatively. All normal children display this inner drive for pictorial creation. Drawing on walls, doors, pavements are visible proofs of the child's inborn creativeness.

\section{Child Development Through Art Learning}

Art has been known to be a discipline or subject that helps in the emotional, physical, perceptual, intellectual, social, aesthetic and cognitive development of a child. All these put together will propel the child to ideal and consummate growth towards future challenges and demands in societal and national developments.

\section{Emotional Development of a Child}

In the area of emotional development of the child, Art is a subject that evokes feelings of attachment. In this regard, the child develops a feeling of ecstasy that ensues in the process of what looks like a journey, suffice to say, an adventure in producing a piece of Art work. This attachment and feelings that develop in this process grow with the child and the same becomes part of the child as he or she engages in other life's endeavours that would require concentration and emotional attachment for total success.

\section{Physical Development of a Child}

Art also plays a tremendous role in a child's physical development. In this regard, the scribbling stages of the artistic life of the child help the child in developing motor skills that catalyze the muscle development for constant physical motions. In this regard constant Art activities of the child bring about physical development. Constant use of Art materials like crayons, pencils, clay, etc. stabilizes the hand and emboldens it.

Hassan (2000) explained that Art shows the child in the early stage of three to four years how to grasp a crayon or pencil and make marks all over the place at home or at school. He enjoys holding and moving the crayon up and down or in circles, scribbling all over the place. By so doing he/she is developing his muscles and controlling his/her tiny hands. This can continue for months before he/she can start moving his/her hands to form lines, circles, drawing of "stupid" pictures or things without meaning to adults but could be meaningful to him. At this stage, the teacher should encourage him by giving him colours, paper and other simple Art materials that are 
available to draw or scribble and create what his/her feelings tell him/her to do.

\section{Perceptual Development of a Child}

Perceptual development of the child becomes glaring with Art education (learning). Here the child's sense develops towards visual observation of colours. This also gives rise to awareness of space and environment. More so, as the child kneads and works with clay and feels the textures, the child enters one level of perceptual growth or development to another.

\section{Intellectual Development of a Child}

Intellectually Art experiences help a child to develop consciously and unconsciously. Here constant Art activity brings about maturation and aspiration for the best. For instance, if a child, four (4) years old, draws a man with big head when the child continues Art learning up to age eight or nine, he or she would draw a man with a head that is proportional to all other parts of the body. This is intellectual growth, this will on the long run bring about excellence in the child's artistic development and other areas of his or her life.

\section{Social Development of a Child}

Social development of the child becomes pronounced through Art learning. The closest companion of a growing child is humans, that is, the mother, father, relations, classmates and other peer groups. The child being captivated by these on leaving the scribbling stage concentrates in drawing human beings and nearly everything he or she picks up pencil or crayon. This is because human being dominates the child's visual world. This leads to constant interactions and steady social growth in the child.

\section{Aesthetic Development of a Child}

Art learning no doubt produces aesthetic development in a growing child. Aesthetics can be defined as the means of organizing thinking, feeling and perceiving into an expression that communicates these thoughts and feelings to someone else. Organization of lines, shapes, colours, and form makes up Art and organization tones make up music (Lowenfeld \& Brittain, 1975). As the child uses lines, shapes, colours, etc. he or she packages or produces Art works that will draw people's attention; by this also, the child presents himself because with this arrangement his audience would always identify his works. Seeing Picasso's works one will surely relate them to Picasso. So, through the use of lines, shapes, colours, and forms beauty (aesthetics) and personality of the Artist is portrayed.

\section{Cognitive Development of a Child}

Art making also does a lot in helping a child's cognitive development. When a child chooses media, arranges objects i.e., planning his/her work, he or she gains more understanding and knowledge of the Art activity. As the child grows to adulthood he or she would have gotten used to the profession and can transfer the knowledge so gained into architecture and other technical activities.

In his contribution, Adetoro (2013) submitted that doing Art can help the children engage many of their senses, especially those of sight and touch. In addition to the heightening their senses, Art makes children more aware of the physical environment in which they live. Art can help further children's creative, social and emotional abilities. Muscle co-ordination and motor skills are developed when children engage in Art. Proof of this is found in the scribbling stage of artistic development. Altogether, a child needs more of Art to develop properly, than any subject. Other subjects may be important but Art is the foundation. 


\section{Computer and Art as Joint Resource for Child Development}

When computer literacy begins at cradle, achievement of indigenous skills and competencies will be faster, consistent and progressive for empowered economy and people. Countries like China, Malaysia, Korea, and Singapore and so on, are good examples of nations that have encouraged computer literacy and Information Technology (IT) advancement (Okechukwu \& Amadi, 2012).

A scientist, an accountant, a banker, a business man, etc. all need the computer for the running of their day-to-day calculations, analysis, programming, accounts balancing, etc. In the first instance, this is why the computer was invented. Suffice it to say that the computer which is equipped with drawing programme means more to a growing child. For instance, graphics packages like Corel Draw and Auto CAD have icons that can allow the user generate different shapes and that could be used in producing drawings and designs. Infact with these, drawings become easy. Alongside there are also pallets that could be used in painting the drawn images.

With the keyboard, the mouse, the screen and any of the graphics packages a child begins to create his own pictures with the guidance of a teacher. Constant drawing practices with the computer will no doubt bring about perfection which will eventually lead the child into knowing how to use the computer in desktop publishing, typesetting document and very many other things.

\section{Computer in Art Training}

Art no doubt becomes salient here because a child who has passed the scribbling age and has started drawing well to an extent having developed artistically can make several drawing adventures with the computer while guided by the teacher. In this regard a child that has started holding the pencil well to draw can as well move the mouse in a drawing adventure. This is because over time, scribbles and drawings with pencil would have also developed the muscle to handle the mouse. More so, the child's knowledge and use of colours during his/her painting exercise becomes a stimulant in using the colour pallet in the Corel Draw application package or other graphics packages available. In this regard the Art resources, like creativity imagination, aesthetics, conception which have all been unconsciously imbibed by the child become armouries in the child's use of computer in his/her drawing activities.

With these basics and this foundational knowledge of the computer made possible by the early Art education of the child, it becomes possible for the child to begin to explore other aspects of the use of the computer in producing pictures. At the secondary and tertiary educational levels, the child who is now a man or a woman will now be able to use computer in making breakthrough in chosen careers or profession like graphics design, architecture, engineering, etc. In most cases, the works of these professionals give rise to inventions and other scientific discoveries.

\section{Art in Computer Studies}

From the above, the resources in Art become plausible in equipping the growing child in the study of computer. In this regard, the essence of Art in computer studies cannot be over emphasized. The artistic creativity, aesthetics, imaginations, conceptions and skills go a long way in aiding a young learner to make a breakthrough in the use and studies of the computer.

Using the computer, animated pictures produced by artists have become in recent times resources for teaching and learning for the growing child. These motion pictures tell stories about people and situations and go 
a long way in perceptually, intellectually, socially, visually, emotionally, etc., developing and positively affecting the growth of the child. The child learns so much from this because the pictures/cartoons are works of Art and they are animated.

\section{Art and Computer Resources for Creative Learning}

Amadi (2013) posited that an artist is well able to create because he/she is imaginative as well as conceptual. To write programs in the development of graphics (or artistic) packages requires the attributes of Art (conception, imagination, aesthetics, etc.) as well as computer programming skills and tools (programming languages, program translators, computer system, etc.). At the same time the child has the skill to draw what he/she conceives. Those in the engineering and architecture professions need the artistic talent or knowledge to excel in these areas. In the graphic thinking process, which is a creative process, the hand is the skill, the brain or mind is the seat of imagery or imagination; while the eye is for observation. The three-hand, brain and eye work together to conceptualize, create, invent or develop ideas. By this, a growing child will have a quicker knowledge and understanding when the artistic knowledge is combined in the study of the computer.

\section{The Importance of Societal Sensitization in the Use of Art in Child Development}

The need for societal sensitization in the use of any product solves the problem of ignorance and increases productivity. In the case of the use of Art in learning and development of a child; passion for Art, patience and demonstrations of place of Art in teaching and learning informed the results (See Appendix A).

\section{Discussion}

People in our locality (Nasarawa, Nigeria) have embraced the importance of Art in teaching and learning after six long years of sensitization and campaign by the pioneer head of the Department of Art and Industrial Design in the Federal Polytechnic, Nasarawa, Nigeria. Initially he was nicknamed "HOD without students and office/classroom”. After two years, his nickname changed to "HOD with few students that have nothing doing but go about drawing irrelevant things". The school authority was reluctant to advertise the Art programme in the school. The few students the department got in subsequent years were those that could not get admission into the so-called "prestigious courses" (like architecture, engineering, law, etc.). Parents reluctantly allowed their wards to enrol into the Department of Art \& Industrial Design as an alternative to staying idle at home.

In the sixth year of the existence of the department, the pressure for admission became too much, meaning that awareness on the importance of Art in child development has been achieved. Many parents and pupils prefer the Art \& Industrial Design to "prestigious" architecture, mass communication, agriculture, etc. The results from our respondents in the Appendix A show how much the Nasarawa community has been sensitized on the role of art in child development. The entrepreneurial skills, as well as commercial values of products of Art for economic turnaround of the community at large have also made the department the "toast" of the locality. The demand to include Art training in the primary and secondary schools' curricular is obvious by the outcome of the research results in the Appendix A. Hence, Art has taken the driving seat of the Entrepreneurial Department of the Federal Polytechnic, Nasarawa, Nigeria.

\section{Conclusion}

Suffice it to say that knowledge to be drawn or gained from the study of Art is not just for Art alone. The 
resource or attributes of Art make Art a must study for the engineer, architect, medical scientist, etc. For instance, the artistic skill is needed in engineering design production, architectural design and draftsmanship, to add to these, not many people know that the artistic skill is required in surgical operation. More so, medical illustrations by artists are what medical students use in their study of medicine.

Amadi (2013) attests that the resources in Art like aesthetics, creativity, conception, skill and imagination being key players in inventions and productivities are no doubt the hubs of entrepreneurship. In the first place an entrepreneur, that is, a business owner or manager has to be skilful, imaginative, conceptual, creative as well as aesthetic minded to be successful. With all these resources, an artist has an encompassing knowledge about nearly everything. Mamani (2008) in Amadi (2013) posited that Art means skill, its display or applications. It means skill in doing anything as a result of the knowledge and practice. It means skill in applying the principles of a special science, technical or professional skills, and the application of skill to subject of taste as poetry, music, dancing, drama, oratory, literary composition and the likes. Art means the application of skill to the arts of imitation, invention, innovation and design like painting, engraving, sculpture and architecture. The cultivation of these principles and practice result to the skilful production of the beautiful invisible forms. Art is a practical application of any science, a body of system of rules serving to facilitate the carrying out of certain principles. Art is an acquired faculty of any kind, a power of doing anything wherein skill is attained by study and practice.

From the above, it becomes pertinent that Art studies be made compulsory at the kindergarten, the primary and secondary levels of education. With Art studies, future creative minds will be developed for national growth and achievement in education, science and technology, etc.

\section{References}

Adetoro, S. A., \& Falayi, T. O. (2013). Children's art: An examination of historical and contemporary concept of the issue especially in Nigeria and Africa with some reference to training towards textile decoration, fabric construction and clothing. In 1 st National Gallery of Art National Children Art Exhibition. Abuja: National Gallery of Art.

Akpaide, U. U. (2006). The place of art in education. In The Symposium on Nigeria Art. Abuja: National Gallery of Art.

Amadi, F. O. (2012). Art in creativity and inventions (paper presented at The 8th Annual National Conference of the National Association for Encouraging Qualitative Education in Nigeria (ASSEQEN), Monday 14-Friday 18 May, 2012. Ebonyi State University, Abakaliki).

Amadi, F. O. (2013). The role of art in industrial and technological development. Nasarawa: Semtec.

Emeriewen, K. O., \& Omatseye, B. O. J. (2009). The Nigerian primary school curriculum and the need for art integration. In Art in contemporary Nigeria: Its value and appreciation. Abuja: National Gallery of Art.

Hassan, M. S. (2000). Art as a therapy to effective teaching in primary school level. Zane Journal of Art Education, 1, 9-12.

Hornby, A. S. (2010). Oxford advanced learner's dictionary. Oxford: Oxford University Press.

Lowenfeld, V., \& Brittain, W. L. (1975). Creative and mental growth. London: Macmillan.

Microsoft ${ }^{\circledR}$ Encarta ${ }^{\circledR} 2009$ (DVD) Redmond, W. A.: Microsoft Corporation 2008.

Okechukwu, P. I., \& Amadi, F. O. (2012). Fast-tracking indigenous skills and competencies development: IT template. Info Search Journal, 3, 51-60.

Oloidi, O. (2011). The rejected stone: Visual arts in an artistically uninformed Nigerian society. In The 58th Inaugural Lecture of the University of Nigeria. Nsukka: University of Nigeria Senate Ceremonial Committee.

Oloidi, O. (2013). Sowing creative seed of socio-technological development: Child art education in Nigeria. In First National Gallery of Art National Children Art Exhibition. Abuja: National Gallery of Art. 


\section{Appendix A}

The set of fifteen questions that were used in the survey among 20 persons as sample size in each of the two separate surveys (i.e. 40 persons), were used among staff, students and pupils in the tertiary, secondary and primary school levels in Nasarawa, Nigeria. The same set of questions were used, but the ones served in the tertiary level were in positive form, while the ones served in the secondary and primary levels were in the negative form (i.e. fixing NOT in the same questions). The results are depicted as in Table 1 and Figure 1 (for Tertiary level) and Table 2 and Figure 2 (for Primary and Secondary levels) below.

The Questions that culminated to the response groupings in the tables and charts below considered the following factors:

- Art and the emotional, creative skills as well as physical development of a child;

- Attraction of Art for the development of entrepreneurial skills;

- Early exposure to imaginative potentials of a child through art training;

- Computer and Art as joint resources for child development;

- Discovery of the child's technical potentials through Art training;

- Art as tool for better knowledge of science;

- Art training as the fastest method in enabling a child express himself/herself aesthetically and pictorially by way of inventions. Note: The choice of the use of pie and line charts in depicting the response groupings is to explicitly show the strengths of the response groupings, and show awareness level for Art in child development.

Table 1

Analysis of the Data Collected From a Sample Size of 20 Randomly Selected, in Response to 15 Questions (in Tertiary Level)

\begin{tabular}{lll}
\hline Decision Type & Frequency & Percentile \\
\hline St. Agreed & 100 & 33.3 \\
Agreed & 164 & 54.7 \\
Undecided & 11 & 3.7 \\
Disagreed & 19 & 6.3 \\
St. Disagreed & 2 & 0.7 \\
Null & 4 & 1.3 \\
Totals & 300 & 100 \\
\hline
\end{tabular}
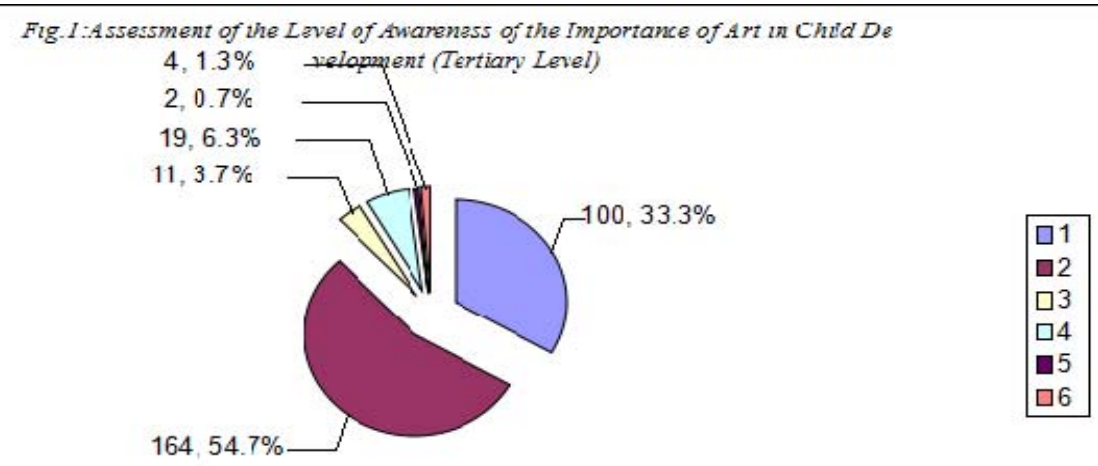

Figure 1. Assessment of the level of awareness of the importance of art in child development (tertiary level). 


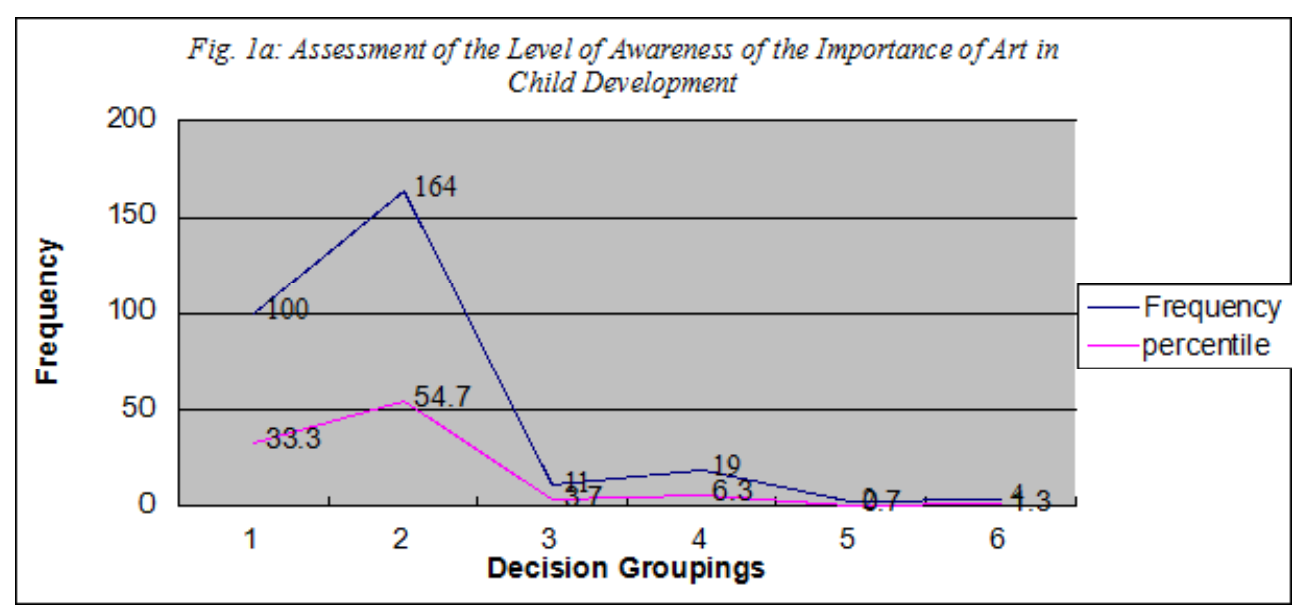

Figure 1a. Assessment of the level of awareness of the importance of are in child development.

Table 2

Analysis of Data Collected From a Sample Size of 20 Randomly Selected in Response to 15 Questions (in Primary \& Secondary Levels)

\begin{tabular}{lll}
\hline Decisions & Frequency & Percentile \\
\hline St. Agreed & 27 & 9.0 \\
Agreed & 64 & 21.3 \\
Undecided & 18 & 6.0 \\
Disagreed & 148 & 49.3 \\
St. Disagreed & 36 & 12.0 \\
Null & 7 & 2.3 \\
Totals & 300 & 100.0 \\
\hline
\end{tabular}

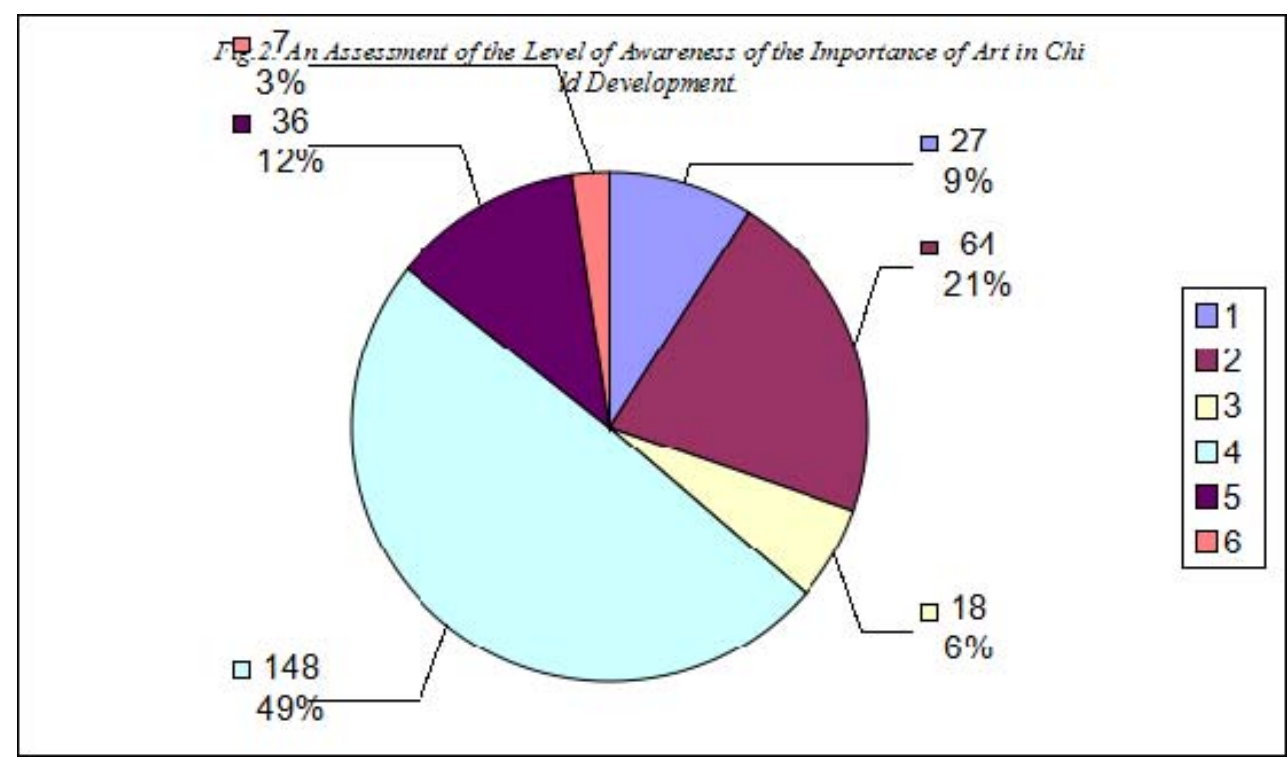

Figure 2. Assessment of the level of awareness of the importance of art in child development. 


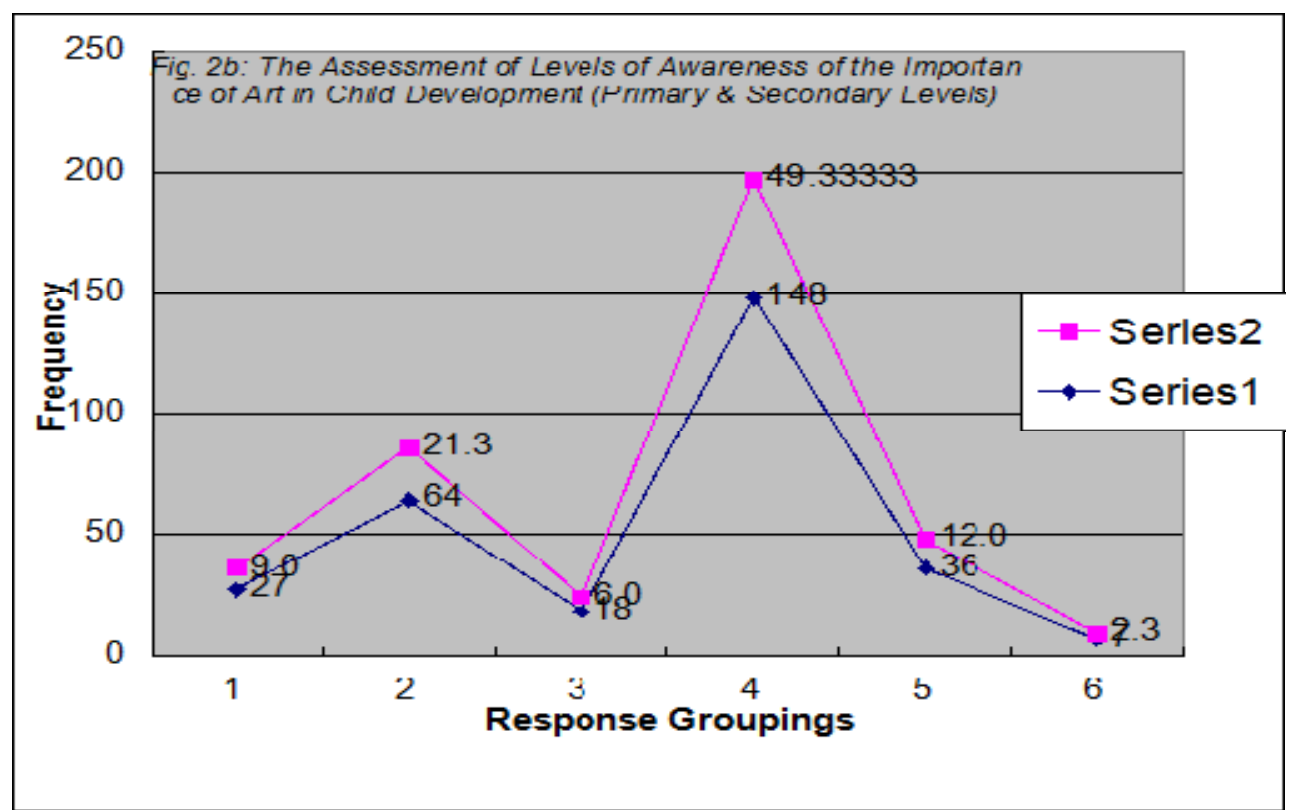

Figure 2a. The assessment of levels of awareness of the importance of art in child development (primary \& secondary levels). 